\title{
Potentiality of Different Varieties of Fig for Rooting of Cuttings under Open and Shade House Conditions in Northern Dry Zone of Karnataka, India
}

\author{
Prema Kuntagol*, D. R. Patil, Venkateshalu, I. B. Biradar, \\ M. S. Nagaraj, G. Manjunath and D. P. Prakash \\ Department of Fruit Science, College of Horticulture, Bagalkot-587 104, Karnataka, India \\ *Corresponding author
}

\author{
A B S T R A C T
}

\begin{tabular}{|c|}
\hline Keywords \\
\hline $\begin{array}{l}\text { Varieties of fig. } \\
\text { Growing conditions. } \\
\text { Plant propagation. }\end{array}$ \\
\hline Article Info \\
\hline $\begin{array}{l}\text { Accepted: } \\
\text { 15 September } 2017 \\
\text { Available Online: } \\
10 \text { November } 2017\end{array}$ \\
\hline
\end{tabular}

Propagation of the fig tree predominately uses hardwood cuttings obtained from pruning stock plants. With a view to optimizing fig tree propagation, the effects of different growing conditions on the rooting of hardwood cuttings from the five varieties of fig were evaluated. An experiment was set up in a two factorial design, with two growing conditions (Open and Shade house) and different varieties (Poona, Deanna, Bellary, Dinakar, Conadria), 90days after starting the experiment, rooting, root length, survival percentage were all evaluated. The interaction of the growing condition and varieties was significant for rooting, sprouting, and root length. The results of the investigation indicated that, among two of growing conditions, cuttings under open condition recorded maximum root growth, percentage of rooted cuttings, survival percentage of rooted cuttings. In respect of different varieties, cuttings of Dinakar under open condition gave maximum root growth, Deanna gave percentage of rooted cuttings, survival percentage of rooted cuttings in all varieties cuttings, thus fig can be propagated under open condition with natural tree shade.

\section{Introduction}

The genus Ficus, commonly known as fig belongs to the family Moraceae and constitutes an important group of trees. Among them, Ficus carica L. is the most popular and economically important species. It is a subtropical and large, deciduous shrub or small tree of $3-9 \mathrm{~m}$. The fig is a native of Asia Minor and spread early to Mediterranean region. It is a plant of extremely ancient cultivation and reported to be under cultivation from 3000-2000 BC in the eastern Mediterranean region (Dawange et al., 2016). The fig fruit is unique, known as a false fruit or multiple fruit. The fig fruit is an inverted flower with both male and female flower parts enclosed in stem tissue. This structure is botanically known as a "synconium".

Asexual method of propagation is one of the paramount methods to propagate the fruit crops. This is very useful for replicating true to type clonal planting material, enables germplasm conservation, introduction of fast growing species and multiplication of elite plants for planting purpose. Thus it has emerged as the most important, fast and convenient economic propagation technique to raise superior planting material. Fig is not an exception to this and is also propagated by asexual means primarily through hardwood 
cuttings. In comparison to other methods of asexual propagation in fig, propagation by stem cutting has been the modern commercial nursery practices as a rule (Aminove, 1972). Fig is hard to root. Although fig can strike roots but rooting is not appreciable. Currently, commercial fig (Ficus carica L.) nursery tree production is mainly based on cuttings taken from the mother plant which are placed in a rooting or growing medium to give rise to roots and shoots thus forming a new plant identical to the mother plant. However, success in propagation through cuttings depends on both environmental factors as well as genetic factors like rooting potential of the cultivar and age of planting material. In general, in commercial fig nursery tree production, growers are often confronted with problems in rooting of hardwood cuttings. The response of different cultivars to rooting varies with different growing conditions. The research on this aspect is very meager. Hence, in order to standardize the optimum growing conditions for maximum rooting of hardwood cuttings, the present investigation was under taken.

\section{Materials and Methods}

The field experiment was conducted at Department of Fruit Science, University of Horticultural Sciences, Bagalkot. It is situated in the northern dry zone of Karnataka. The experiment was conducted by using two growing conditions (Open and Shade house) and five different varieties (Poona, Deanna, Bellary, Dinakar, Conadria) of fig with ten treatments and three replications in factorial randomized block design. The total numbers of cuttings included in the each replication were 30. In the present experiment, natural shade of the trees in open was considered as open condition. Green coloured shade nets were used to provide 50 per cent shade allowing only 50 per cent sunlight. Low temperature with high humidity was maintained in comparison with outside environment.

Two sprouted cuttings were selected randomly from each treatment in each replication. These two cuttings were used for recording the observations on root parameters. Percentage of rooted cuttings was calculated by using the following formula at 30 days after planting.

Percentage of

Number of cuttings rooted Rooted cuttings $(\%)=$ $\mathrm{x} 100$

Total Number of cuttings

The root length of each rooted cutting was measured from the base to the tip of root with the help of measuring scale and the mean length was calculated. The total number of roots per cutting was counted under each treatment at $90^{\text {th }}$ day after planting and the mean was calculated and expressed in numbers. The total number of rooted cuttings survived under each treatment in each replication was recorded and survival percentage of rooted cuttings was calculated at 90 days after planting.

The data was analyzed using computer software programmed by the method of variance outlined by Panse and Sukhatme (1978). Statistical significance was tested by $F$ value at 5 per cent level of significance.

\section{Results and Discussion}

Among the growing conditions, open condition recorded significantly maximum percentage of rooted cuttings $(33.65 \%)$ compared to shade house (26.39\%). Maximum percentage of rooted cuttings in open condition was due to the production of more number of roots and root length which helped in compensating the high evapotraspirational losses under open 
condition compared to shade house condition. Similar results were reported by Bhatt and Tomar (2011) in Citrus aurantifolia (Swingle) cuttings in open conditions compared to polyhouse conditions. Deanna recorded maximum percentage of rooted cuttings $(38.92 \%)$ among the varieties (Table 1$)$. The genetic variation was reflected in their response to different growing conditions. From this prospective, it was clear that Deanna, Conadria and Poona having high percentage of rooting capacity and have more advantage than other two varieties viz. Dinakar and Bellary, which had significantly lower rooting potentiality. The similar findings were reported by Saed (2010) in different varieties of pomegranate. Significantly, the highest percentage of rooted cuttings (42.94\%) was recorded in Deanna under open condition. This might be due to the contribution of favourable growing conditions and genetic variation among the varieties.

Open condition recorded significantly highest number of roots per cutting (19.90) over the shade house condition (15.76). Highest number of roots in open condition may be due to more uptake of water by evapotranspiration loses from shoots. Hartmann et al., (2007) who reported that evapotranspiration loses from shoots is more in open conditions to meet the requirement of water, more number of roots develop to absorb more water. ElDaly (1998) also reported that increase in light intensity and temperature would have also favored accumulation of protein in the leaves of cuttings and there by induced more number of roots in hibiscus. Among the varieties, cuttings of Conadria recorded significantly highest number of roots per cutting (19.90).

This was probably due to inherent character of different varieties with respect to root parameters as Conadria produce more number of roots (Table 2) while, less number of roots was recorded in Dinakar (14.63). Significantly, the highest number of roots (22.67) per cutting was noticed in Conadria under open condition (Table 2). The genetic variation might have reflected in the differences noticed among the cultivars in their response to different growing condition. Lowest average number of roots (12.93) per cutting was recorded in Dinakar.

Table.1 Percentage of rooted cutting in different varieties of fig as influenced by growing conditions

\begin{tabular}{|l|l|l|l|}
\hline \multirow{2}{*}{ Varieties $(\mathbf{V})$} & \multicolumn{2}{|l|}{ Growing conditions $(\mathbf{C})$} & \multirow{2}{*}{ Mean } \\
\cline { 2 - 3 } & Open condition & Shade house & 36.34 \\
\hline $\mathbf{V}_{\mathbf{1}}$-Poona & 38.35 & 34.33 & 38.92 \\
\hline $\mathbf{V}_{\mathbf{2}}$-Deanna & 42.94 & 34.89 & 23.62 \\
\hline $\mathbf{V}_{\mathbf{3}}$-Bellary & 26.61 & 20.63 & 22.13 \\
\hline $\mathbf{V}_{\mathbf{4}}$-Dinakar & 22.22 & 22.04 & 36.62 \\
\hline $\mathbf{V}_{\mathbf{5}}$-Conadria & 38.35 & 34.88 & \\
\hline Mean & 33.66 & 29.39 & $\mathbf{V} \mathbf{x}$ \\
\hline & $\mathbf{V}$ & $\mathbf{C}$ & 1.04 \\
\hline SEm $\mathbf{}$ & 0.73 & 0.46 & 3.08 \\
\hline CD at 5\% & 2.18 & 1.38 & $2017)$ \\
\hline
\end{tabular}

Data on Percentage of rooted cuttings was recorded 30days after planting $\left(6^{\text {th }}\right.$ March, 2017) 
Table. 2 Number of roots per cutting in different varieties of fig as influenced by growing conditions

\begin{tabular}{|l|l|l|l|}
\hline \multirow{2}{*}{ Varieties (V) } & \multicolumn{2}{|l|}{ Growing conditions(C) } & \multirow{2}{*}{ Mean } \\
\cline { 2 - 3 } & Open condition & Shade house & 19.24 \\
\hline $\mathbf{V}_{\mathbf{1}}$-Poona & 22.23 & 16.26 & 16.42 \\
\hline $\mathbf{V}_{\mathbf{2}}$-Deanna & 18.45 & 14.39 & 18.95 \\
\hline $\mathbf{V}_{\mathbf{3}}$-Bellary & 19.80 & 18.10 & 14.63 \\
\hline $\mathbf{V}_{\mathbf{4}}$-Dinakar & 16.33 & 12.93 & 19.90 \\
\hline $\mathbf{V}_{\mathbf{5}}$-Conadria & 22.67 & 17.14 & \\
\hline Mean & 19.90 & 15.76 & $\mathbf{V} \mathbf{x} \mathbf{C}$ \\
\hline & $\mathbf{V}$ & $\mathbf{C}$ & 0.86 \\
\hline SEm $\mathbf{\text { V }}$ & 0.61 & 0.38 & 2.55 \\
\hline CD at 5\% & 1.80 & 1.10 & \\
\hline
\end{tabular}

Table.3 Root length $(\mathrm{cm})$ per cutting in different varieties of fig as influenced by growing conditions

\begin{tabular}{|l|l|l|l|}
\hline \multirow{2}{*}{ Varieties (V) } & \multicolumn{2}{|l|}{ Growing conditions(C) } & \multirow{2}{*}{ Mean } \\
\cline { 2 - 4 } & Open condition & Shade house & 14.89 \\
\hline $\mathbf{V}_{\mathbf{1}}$-Poona & 17.65 & 12.11 & 12.03 \\
\hline $\mathbf{V}_{\mathbf{2}}$-Deanna & 13.68 & 10.37 & 15.70 \\
\hline $\mathbf{V}_{\mathbf{3}}$-Bellary & 16.28 & 15.12 & 17.77 \\
\hline $\mathbf{V}_{\mathbf{4}}$-Dinakar & 18.62 & 16.91 & 16.34 \\
\hline $\mathbf{V}_{\mathbf{5}}$-Conadria & 18.28 & 14.40 & \\
\hline Mean & 16.90 & 13.78 & $\mathbf{V} \mathbf{x}$ \\
\hline & $\mathbf{V}$ & $\mathbf{C}$ & 0.40 \\
\hline SEm $\mathbf{I}$ & 0.28 & 0.18 & 1.19 \\
\hline CD at 5\% & 0.84 & 0.53 & \\
\hline
\end{tabular}

Table.4 Survival percentage of rooted cutting in different varieties of fig as influenced by growing conditions

\begin{tabular}{|l|l|l|l|}
\hline \multirow{2}{*}{ Varieties (V) } & \multicolumn{2}{|l|}{ Growing conditions $(\mathbf{C})$} & \multirow{2}{*}{ Mean } \\
\cline { 2 - 3 } & Open condition & Shade house & 72.70 \\
\hline $\mathbf{V}_{\mathbf{1}}$-Poona & 75.60 & 69.79 & 75.40 \\
\hline $\mathbf{V}_{\mathbf{2}}$-Deanna & 76.56 & 74.24 & 73.01 \\
\hline $\mathbf{V}_{\mathbf{3}}$-Bellary & 77.14 & 68.88 & 66.66 \\
\hline $\mathbf{V}_{\mathbf{4}}$-Dinakar & 68.25 & 65.08 & 68.16 \\
\hline $\mathbf{V}_{\mathbf{5}}$-Conadria & 70.95 & 65.37 & \\
\hline Mean & 73.70 & 68.67 & $\mathbf{V} \mathbf{x}$ \\
\hline & $\mathbf{V}$ & $\mathbf{C}$ & 2.95 \\
\hline SEm \pm & 2.09 & 1.32 & NS \\
\hline CD at 5\% & 6.20 & 3.92 & \\
\hline
\end{tabular}

NS- Non significant 
Among the growing conditions, open condition recorded significantly maximum root length $(16.90 \mathrm{~cm})$ compared to the shade house condition $(13.78 \mathrm{~cm})$. This might be due to the fact that evapotranspiration loss of water from shoots is more in open conditions to meet the requirement of water, more number of roots and longest root was developed to absorb water from deeper layers (Hartmann et al., 2007). However, the rooting parameters were recorded low under shade house conditions, which might be due to presence of high humidity leading to low evapotranspiration for which roots may not require to grow at deeper depths.

Maximum root length $(17.77 \mathrm{~cm})$ was recorded in Dinakar and significantly superior over other treatments. This might be due to genetic variation among different varieties and also difference in the carbohydrate contents in cuttings which is considered as an important factor that determines the variability in rooting capacity of different varieties (Hambricket al., 1991; Hartman et al., 1997) while, Deanna showed minimum root length $(12.03 \mathrm{~cm})$ per cutting. The highest root length $(18.62 \mathrm{~cm})$ was recorded in Dinakar under open condition (Table 3) and was significantly superior over other treatment combinations.

Among the growing conditions open condition recorded significantly maximum survival percentage of rooted cuttings $(73.70$ $\%)$ compared to the shade house $(68.67 \%)$. This may be due to the production of more number of roots and root length under open condition which helped to withstand high evapotranspirational losses. Similar results were recorded with Citrus aurantifolia (Swingle) cuttings in open conditions compared to polyhouse conditions (Bhatt and Tomar, 2011).The survival percentage of rooted cuttings was significantly influenced by the varieties (Table 4). Cuttings of Deanna variety recorded highest survival percentage (75.40 \%). Least value was recorded in Dinakar (66.66 \%). This might be due to production optimum number of roots by endogenous growth substances. Hartmann and Kester (1989) also reported that the presence of differential levels of endogenous rooting cofactors and carbohydrates and their differential behavior in different growth parameters. The interaction between the growing conditions and varieties on survival percentage of rooted cuttings was found to be non-significant. However, Bellary variety recorded highest survival percentage (77.14 $\%)$ under open condition.

It can be concluded from the results of the present study, open condition proved better for root growth and survival compared to shade house condition. Among the varieties, Deanna performed well with respect to, rooting and survival percentage and was on par with Poona. These technologies would go a long way in improving the turnover efficiency of availability of rooted cuttings per unit time to meet the increasing demand of growers' as well as nursery men for the multiplication of fig plants.

\section{References}

Aminove, K. H. L., 1972, Subtrop. Kul'tury, 6:91-107.

Bhatt, B. B. and Tomar, Y. K., 2011, Effect of IBA and growing conditions on vegetative performance of Citrus aurantifolia (Swingle) cuttings. J. Hill Agri., 2(1): 98-101.

Dawange, G., Dahale, M. H., Satkar, K. and Gawande, S. C., 2016, Effect of different concentrations of plant growth regulators on growth, rooting and survival of hard wood cuttings of fig. Advances in Life Sci., 5(10): 2278-3849.

El-Daly, F. A., 1998, Impact of temperature and light conditions on some metabolic 
aspects easy (variety Holiday) and hard to root (variety cardinal) cuttings of Hibiscus rosa-sinensis L. during rooting.Egyptian J. Phys. Sci., 22:357375.

Hambrick, C. E., Davis, F. T. and Pemberton, H. B., 1991, seasonal changes in carbohydrate/nitrogen levels during field rooting of Rosa multifora hardwood cuttings. Scentia hort., 46: $137-146$.
Hartmann, H. T. and Kester, D. E., 1989, Plant propagation, principles and practices. Prentice Hall, New Delhi.

Hartmann, H. T., Kester, D. E., Davies, F. T., Geneve, R. L., 2007, plant propagation principles and practices, 299.

Panse, V. G. and Sukhatme, P. V., 1978, Statistical method of agricultural workers, ICAR Publication. New Delhi, 381.

\section{How to cite this article:}

Prema Kuntagol, D.R. Patil, Venkateshalu, I.B. Biradar, M.S. Nagaraj, G. Manjunath and Prakash, D.P. 2017. Potentiality of Different Varieties of Fig for Rooting of Cuttings under Open and Shade House Conditions in Northern Dry Zone of Karnataka. Int.J.Curr.Microbiol.App.Sci. 6(11): 1763-1768. doi: https://doi.org/10.20546/ijcmas.2017.611.212 